\title{
Who Will Save Nigeria? : On Writing And The Writer's Role In Securing The Nation
}

\author{
Kahar Wahab Sarumi \\ Department of Islamic Studies, School of Arts and Social Sciences, \\ National Open University of Nigeria, Lagos
}

\begin{abstract}
How might writers use the art of writing to stoke up the consciousness of the Nigerian public to the nation's security challenges? How might authors deploy the writing skill to channel a way out of the nation's security dilemmas in order for her to reach Platonic Nirvana, which is said to be the desire of nation-states and political entities? In other words, how can writers help solve the socio-political, economic, and security crises in which the nation is stuck? Should writers occupy the position of passive witnesses or take up active roles through the medium of writing in order to effect change? Should they tell the truth and be damned or tell lies and be done for? These questions are premised against the current state of insecurity bedeviling Nigeria as a nation and the consequent negative image it continues to suffer on the local and foreign media. The paper is equally hinged on the assumption that writing as an art is a plausible means through which safety and security could be promoted especially in a crumbling nation such as Nigeria. The paper benefits from a blend of methods including historical, descriptive and analytical. It derives its discussion from such writers as Edward Said, Najib Mahfuz, Christopher Okigbo, Maman Jiya Vatsa and Ken Saro-Wiwa to mention but a few.
\end{abstract}

Keywords: Boko Haram, Insecurity, Nigeria, Security, Terrorism, Writing.

\section{Introduction}

Since Nigeria became an independent state in 1960, her aspiration to nationhood has been punctuated regularly and perilously by deep-seated insecurity, including a civil war in which over a million Nigerians died. Apart from the civil war of 1967 to 1970, ethno-communal clashes, religious conflicts, electoral violence and different struggles for natural resources, particularly petroleum resources in the Niger Delta region, have at different times brought the country to a dangerous situation. During a long period of military rule, conspicuous human rights violations, repression of opposition and terrorization of the citizenry through misuse of the police, incessant deployment of the military to police duties and widespread immunity for people in power, created a general atmosphere of insecurity across the country. Gradually, between a repressive state that lacked legitimacy and an intimidated citizenry, a vacuity emerged and was filled by criminality - armed robbery, pipeline vandalization, rape, racketeering, corruption, kidnap for ransom and terrorism - and this has persisted. In fact, a recent study shows that more than two-thirds of Lagos residents fear that they might be crime victims. ${ }^{[1]}$ And today, residents of Northern Nigeria and particularly those of Bornu State and the bordering cities live between terror, horror and hope, as they sleep with one eye open and the other close. Nigerian writers and critics have attempted to plumb the inner portals of the reality of security situation in Nigeria, either as a lens through which Nigeria's socio-economic and political landscape could be viewed, or as a counterfoil for the country's trials, travails and triumphs; or even as a periscope to see her destiny and destination.

This paper intends to show that the deplorable security situation in Nigeria signposts the malfunction of the country's leadership and that writing as an art is a possible means through which safety and security could be promoted in the nation. The current state of insecurity in Nigeria catalogues the end and the beginning of the old and new generations in Nigeria's ruling and, indeed "democratic" class. The pathos of the state of insecurity heralds an implosion within the country's socio-political landscape, which is destined to, one; evolve insurgent groups including the Boko Haram component of the Nigerian landscape; and two, dictate a new path in the negotiation of the slippery Nigerian social and political terrains.

In approaching this essay, we shall operate within two inter-related frameworks. First is Abul Aswad's view of the learned and rulers that "sovereigns are rulers over people, but it is the learned who rule over the sovereign.."[2] The other, which proceeds from Zubair Ibn Bakkar, asserts that "writers are rulers over people". Thus, it shall be our task to examine national security in the context of Nigeria, and to plumb the origins of insecurity in the country, before proceeding to explore how the art of writing could be deployed to promote safety and security in Nigeria. 


\section{National Security In The Nigerian Context}

Security means protection from sudden and cruel disruptions in the patterns of daily life in residences, offices or communities. It is the state of being safe and secure from threat and danger of all kinds. It is defense against a misfortune that might befall humanity in the future, and involves all activities capable of protecting persons, a building or a country against threats, peril and perish. ${ }^{[4]}$ Security is essentially related to the presence of peace, safety, happiness and the protection of human and physical resources. It is closely connected to the absence of crises and menaces to human injury. The United Nations Development Programme identifies human security as freedom from such chronic threats as hunger, disease and oppression. ${ }^{[5]}$ Although, it is widely agreed that security is the responsibility of all and sundry, but governments in well organized systems through their security agencies are often more concerned to protect lives and property of the governed. This explains the rationale behind President's or Governor's swearing to an oath, at the inception of their tenure of office, to protect lives and property. Hence, security is a key concern of all tiers of government of any nation, and Nigeria should not be an exception. On the contrary, security and indeed, national security has become a chronic problematic in Nigeria.

\section{Problematizing Security In Nigeria}

For the Nigerian nation and her political elite, what constitutes security is conservatively embedded in the state's monopoly and control of all legitimate mechanisms of oppression, and its ability to bring both internal insurgency and external aggression under control. Security therefore is seen as the exclusive preserve of the state ${ }^{[6]}$ In Nigeria, the idea of security is generally confined to 'national security', which is often equated to state security, and is viewed as the security of those who occupy the upper-ladder of public office. National security is seldom viewed as the welfare and protection of the citizens, neither is security - defined in generic sense - viewed as 'community security', 'societal security' or securing the 'common good ${ }^{\text {, }}{ }^{-7]}$ for citizens at the lower rung of the ladder. Put differently, security is not viewed in social and developmental terms, or in the context of a common humanity and promoting the welfare of the people. Rather, it is viewed purely in state centric and military terms, and perceived as the maintenance of the sovereignty of the Nigerian State. In such circumstances, national security often subverts the security of citizens. Conceivably, this is what the Nigerian public is currently experiencing.

The state normally is charged with the responsibility of protecting the citizen of his/her rights. In Nigeria, the citizen is often the criminalized; state arbitrariness and excesses go unchecked by the law itself hence the euphemistic jargon, 'executive lawlessness'. ${ }^{[8]}$ Whereas the state is viewed as the custodian of the law, the citizen is seen as the custodian of its abuse; the law applies to the citizen and not the state, whose "persona" is abstract and intangible. One may want to submit that this biased delineation of security has the capacity of providing the context for the rise of citizen militancy even as it may affect the culture of judicature. Next to the problem of unfair conception of security in Nigeria is its politicization. Nigerian politicians use state security agencies to further their own interests. Last, but not the least, is the dehumanizing training and poor remuneration offered to law enforcement agents, especially the Nigeria police. This has turned some officers into corrupt and corruptible officers, making the citizens susceptible to insecurity. But what really are the sources and causes of insecurity in Nigeria? Various scholars and writers have attempted to essay the causes for the state of insecurity currently bedeviling Nigeria as a nation; this paper however, indexes only the major sources/causes of insecurity in the contemporaneous Nigeria.

\section{Sources/Causes Of Insecurity In Nigeria}

The antithesis of security is insecurity, which concept has often been construed differently by scholars and writers in relation to the various ways it affects individuals and the state. Some of these include: want of safety and confidence; danger; uncertainty; inadequate protection; lack of protection and stability; trouble, etcetera, which all boil down to reference to a state of susceptibility to harm, loss of life, property or livelihood. ${ }^{[9]}$ Using Beland's phraseology, insecurity is "the state of fear or anxiety stemming from a concrete or alleged lack of protection." ${ }^{[10]}$ A juxtaposition of this definition with the current situation in Nigeria amply situates the country among other insecure nations such as Afghanistan, Pakistan, Somalia, Syria, Sudan, Egypt and Democratic Republic of Congo to mention but a few. But what is responsible for Nigeria's security dilemmas is a question that has engaged and continues to preoccupy the intellectual endeavors of humanitarians, sociologists, religionists, political scientists and specialists in Peace and Security Studies including Andrew and Kennedy ${ }^{[11]}$ Igbuzor ${ }^{[12]}$ Hazen and Honer ${ }^{[13]}$ and Salawu. ${ }^{[14]}$ A thorough scrutiny of their findings reveals that the causes of insecurity in Nigeria are numerous; interlinked and are traceable to internal and external factors, the former reinforcing the latter. Nevertheless, here we focus only on the internal causes, which can be categorized into remote and proximate factors and include the following: 
- $\quad$ Lack of institutional capacity resulting in government failure: This, in the view of Fukuyama, ${ }^{[15]}$ results from the collapse of institutional infrastructures due to instability of their foundations, thus provoking degeneration in state governance and democratic accountability. As Igbuzor rightly observes, the situation can be attributed to government failure to deliver public services and to provide for basic needs of its people. This has made a group of frustrated Nigerians easily ignited into violence by trivial issues. Hazen and Horner described the situation as a 'Paradox of Plenty' whereby the country earns large revenue from oil sales, yet fails to exploit the proceeds to develop infrastructure and the economy for comfort of its people. Hence, the country is stuck at the intersection of criminality and insecurity.

- $\quad$ Pervasive material inequalities: Awareness of disparities in life chances, emanating from the general perception of inequality and marginalization by a section of the people, resulting in disaffection, resentment and grievance. This has made frustrated Nigerians, especially the youths, lose hope and emerge to express displeasure about the state of inequality.

- $\quad$ Ethno-religious conflicts: Arising from fear, distrust, suspicion, and lack of cordiality among diverse ethnic groups and adherents of major religions in the country, thereby predisposing them to violent confrontations.

- Weak security system: Owing to inadequate weaponry and insufficient training for security arm of government. Coupled with this is poor attitudinal and behavioral disposition of some security personnel.

- Loss of socio-cultural and communal value system: What characterize the traditional value system of the Nigerian society are such attractive qualities as collectivism, loyalty to authority, truthfulness, honesty, hard work, tolerance, and love for kith and kin, mutual harmony and co-existence. ${ }^{[16]}$ All these moral values are gradually fading away thus steeping the Nigerian society into an abyss of insecurity.

- $\quad$ Porous Borders: The porosity of Nigeria's frontiers, following her weak security system, smoothens weapons smuggle into the country. As a result, the proliferation of Small Arms and Light Weapons has allowed militant and criminal groups easy access to arms. ${ }^{[17]}$ In fact, Nigeria is estimated to be hosting more than twothirds of about eight million illegal weapons in West Africa. ${ }^{[18]}$ Furthermore, the porosity of the Nigerian borders is facilitating unwarranted incursion of migrants from such adjoining countries like Republic of Niger, Chad and Republic of Benin. ${ }^{[19]}$ Some of the immigrants from these countries are architects of crime in Nigeria.

- Rural-Urban Drift: Another cause of insecurity in Nigeria is the rural-urban exodus of unemployed youths ${ }^{[20]}$ even though the existing infrastructure in most of the metropolitan centers, have been over-utilized. This has resulted in poor living conditions in municipal centers, thereby enticing the youths to go into crime, out of frustration. ${ }^{[21]}$

- Unemployment/Poverty: Following the high rate of unemployment and poverty among Nigerians, particularly the youths, some are tempted into violent crimes. ${ }^{[22]}$ Closely connected to this is inequitable distribution of wealth among the citizens.

- Terrorism: The United Nations Security Council in its 2004 Resolutions defines it as:

criminal acts, including against civilians, committed with the intent to cause death or serious bodily injury, or taking of hostages, with the purpose to provoke a state of terror in the general public or in a group of persons or particular persons, intimidate a population or compel a government or an international organization, to do or to abstain from doing any act. ${ }^{[23]}$

Terrorism has become a global phenomenon and is one of the fundamental sources of insecurity in contemporary Nigeria. This is evidenced by the terror activities of Boko Haram insurgent group; the Niger Delta militia groups; "gunmen" and hostage takers in different parts of the country.

To combat the menace of insecurity in Nigeria, various strategies and approaches have been suggested and designed, including: mass education; improvement of Nigeria's leadership; good governance; socio-economic development; elimination of corruption and entrenchment of social justice; youth empowerment; radical change in values; developing a more balanced security strategy through security sector reform and many others. However, it is a paradox to observe that despite all these recommended solutions, the problematic of insecurity continues to ravage the country like a plague. Nonetheless, this paper hypothesizes that writing as an art is an intellectual means through which safety and security could be promoted in a troubled nation like Nigeria.

\section{On Writing And The Writer's Role In Securing The Nation}

Abul Aswad's view that "sovereigns are rulers over people, but it is the learned who rule over the sovereign", and that of Zubair Ibn Bakkar that "writers are rulers over people" provide us with an alternative or rather a complementary motif for channeling a way out of Nigeria's security problems. This becomes necessary in order for the country to reach Platonic Nirvana, which is said to be the desire of nation-states and political entities. The writer is a citizen and a worker, whose social role contains in the process of writing. The novelist or poet performs a social role of great importance by writing novels and poems which bear witness to the experiences of the society in which s/he resides. A writer would have fulfilled a social function if his/her work helps create awareness about the goings-on in his/her society or if such writing helps inform and enrich an 
awareness not hitherto deeply felt. ${ }^{[24]}$ In other words, intellectuals and writers have a role to play in assisting their people on bringing about change in the society and in alerting and driving their psyches on to the currents of progress and development. Muhammad Ahmad Mahjub puts this stance in sharp focus when he queries: "what would be the value of literature if it does not assist the people on revolution and change in life and in thought and in awakening the minds and propelling it on to the currents of progress and development...?" ${ }^{[25]}$ If this quotation is anything to go by, it lends credence to our theory that literati, intellectuals and learned writers have a role to play in saving their nations, not only from diseases of ignorance, moral decadence and woes of economic fall, but also from tragedies of political collapse and social insecurity.

But how can Nigerian writers help solve the socio-political, economic, and security crises in which the nation is stuck? Should they occupy the position of passive witnesses or take up active roles through the medium of writing in order to effect change? Should they tell the truth and be damned or tell lies and be done for?

The notion that the pen is mightier than the sword perhaps contains the requisite confidence, courage and audacity for Nigerian writers and intellectuals to assume dynamic roles through the podium of writing in order to effect positive change in Nigeria's socio-economic, political and security problems. In his lecture entitled "Representations of the Intellectual", Edward Said explained his concept of "the intellectual" and the importance of this figure for societies in crisis or crises. He submits:

The intellectual is an individual endowed with a faculty for representing, embodying, articulating a message, a view, an attitude, philosophy or opinion to, as well as for, a public. And this role has an edge to it, and cannot be played without a sense of being someone whose place it is publicly to raise embarrassing questions, to confront orthodoxy and dogma (rather than to produce them), to be someone who cannot easily be co-opted by governments or corporations and whose raison d'etre is to represent all those people and issues that are routinely forgotten or swept under the rug. ${ }^{[26]}$

From the foregoing, it is evident that an intellectual acquires the designation not only because of the public role s/he plays, but also due to his/her fundamental responsibility to defend the oppressed and silenced. To Edward Said, the intellectual has a responsibility to operate under two universal paradigms: First, is that every person is entitled to some level of freedom and justice from fellow citizen and the government of his home country. And the other is that "deliberate and inadvertent violations of these standards need to be testified and fought against courageously.",[27]

The views of Najib Mahfuz, an Egyptian writer, novelist and 1988 Nobel Prize Laureate, parallel those of Edward Said (quoted here above) on writing and the writer's role in any given nation. Denouncing all sorts of deviations in the Egyptian society and hoping to awake the consciousness of responsible people among his fellow countrymen, in order to bring about a more equitable and secure social system, Mahfuz wrote:

...I am the first in the alley to have made a profession of writing, although it earned me a great deal of scorn and sarcasm. My job is to write down the complaints of those who are oppressed or in need...I have gained a heart-breaking knowledge of many peoples' secret sorrows. However, I am not writing about myself and my troubles, which are nothing compared with those of the alley. ${ }^{[28]}$

Here we see and understand that Najib Mahfuz appoints himself as nothing but a spokesperson of his people with whom he identifies, believing that only through this kind of commitment would he rouse his audience and would his voice be heard as a writer. We also can observe that his arcade of imagery, in this extract, represents a strong evidence of terrified socio-economic and political system which imprisons his people in a modern period. But Mahfuz strongly believes that he could liberate his people using the weapon of literature as writing to him is but a means of liberation. ${ }^{[29]}$

Accordingly, intellectuals living in such nations in crises as Nigeria ought to assume the role of fighters with pen, that of the rhetoricians and essentially; that of the mouthpieces of the people and their liberators. After all, the pen is acclaimed to be mightier than the sword. For Nigeria writers to occupy the position of passive witnesses to the nation's calamitous events as they descend and unfold would amount to, using Saro-Wiwa's words, "treason" ${ }^{[30]}$ and treachery, for silence sometimes may signify acceptance, consent and indeed approval. Like Najib Mahfuz, such Nigerian writers as Wole Soyinka, Chinua Achebe, Ken Saro-Wiwa and others, through their writing had indicated much interest in the governance and politics of Nigeria. Such books like The Man Died by Soyinka and A Man of the People and the Trouble With Nigeria by Achebe, are some of the books these leading writers had used to stir up public consciousness of Nigeria's problems and solutions to them. ${ }^{[31]}$

In his "Prisoners of Jebs", Ken Saro-Wiwa draws sufficient allusions from the political and economic happenings in Nigeria. He creatively chronicles the regular run of corruption and systematically treats its trend in the Nigerian society. In the satiric narrative, he takes us on an incredible discursive ascent on the mountain of corruption that is Nigeria. Among the many aspects of corruption he covered in the narrative include the overinflation of contract values, and the miscarriage of justice through kangaroo tribunals and courts. Through the medium of satire, Saro-Wiwa confronts the society with its vices and idiocies, and discredits these by using incisive parodies and lampoons. He employs satire as a cultural curative by which he tries to reset the society's 
moral compass, by suggesting an alternative path through which society may rejuvenate its more positive way of life. Further, by means of derision Saro-Wiwa presents a corrective social critique of the nation, Nigeria. ${ }^{[32]}$

But when writers in a nation under siege as Nigeria are forced to tackle the challenge of insecurity from the standpoint of a possible Aesculapian role for their art in society, one may want to ask whether literature guarantees or has ever guaranteed the writer's security himself. The displeasure of nationhood and the selfinflicted psychosis of the Nigerian project have cost Nigerian writers the precious lives of several intellectuals including Christopher Okigbo, Maman Jiya Vatsa and Ken Saro-Wiwa ${ }^{[33]}$ to mention just a few. The killing of these distinguished writers is probably the Nigerian insecurity's way of terrorizing the learned class. If many writers today, and throughout Nigeria's history have been victimized like Wole Soyinka, or exiled like Chinua Achebe or even silenced or put to death like Okigbo, Vatsa and Saro-Wiwa, it shows the seriousness and the impact of their writing on the Nigerian nation-state. Christopher Okigbo was probably the greatest postcolonial, modernist, African poet of the twentieth century. His poetry reflects his paramount concern with the

"ideals of the open society - decolonization of the mind, cultural freedom, human rights and civil liberties, security of life and property guaranteed by the rule of law - ideals which are clearly manifest in his consistent recreations of, and references to "the events of the day" (the traumas of social change, crises of identity, political crises, failure of leadership, violence, and other social upheavals)" ${ }^{[34]}$

Nevertheless, to what extent are these ideals of a free, democratic, just, lawful and purposive society learned, taught and applied to secure the Nigerian nation-space from her current nasty situation? The response to this question perhaps, inheres partly in the ability of Nigerian writers to decolonize the tattered minds of Nigeria's leadership and the battered psyches of its followership. In his book The Trouble with Nigeria, Chinua Achebe observes that "The trouble with Nigeria is simply and squarely a failure of leadership...the Nigerian problem is the unwillingness or inability of its leaders to rise to the responsibility, to the challenges of personal example, which are the hallmarks of true leadership". ${ }^{[35]}$

Mamman Jiya Vatsa, a major-general in the Nigerian Army was a poet. He was executed following an abortive coup. His poetry collections were mostly didactic and nationalistic, with titles such as Back Again at Wargate, Reach for the Skies, Patriotic Poems on Abuja and Verses for Nigerian State Capitals. His writings also mirror his concern about the lives of the ordinary people of Nigeria. ${ }^{[36]}$

From the foregoing, it is clear that the writer's role in contemporary Nigeria is complex. S/he is to testify about the circumstance of Nigerians and to seek to leave a mark in literature by striking a blow at the indifference and ignorance which doom the country to stagnation and misunderstanding. It is the writer's responsibility to explain to people the essential meaning of today's Nigeria, which contains the seeds of tomorrow and the future hope. The seeds of the future should be discovered in the foundation of the present, and the foundation of the present is only laid by writers, philosophers and thinkers in the persons of poets and essayists. The major task of the writer is to struggle for peace and security of the society in which s/he lives. This role is determined, not only by the writer's place in literature but also by the degree of his/her involvement in the society's public life. Said, Mahfuz, Okigbo, Saro-Wiwa, Soyinka and Achebe are all writers, fighters as well as revolutionists. They, in their writings, paid attention to the problems which confront people from day to day. They deployed their writing to expose and condemn all manifestations of evils wherever they appear. In today's Nigeria of increased tension, struggle for identity, threat of disintegration, socio-economic, political and security crises, the writer's civic position, the class and quality of his/her creative work becomes especially vital.

It would be an understatement to say that Nigeria, considering its security situation, is on the threshold of losing its stateliness and self-respect, which according to Achebe is the worst thing that can happen to any nation. ${ }^{\left[{ }^{37]}\right.}$ The writer's duty is to help the nation regain its stateliness by narrating to the text what is happening to it, what it lost. American founding father, Thomas Jefferson, during the Revolutionary War, urged the prominent essayist, Thomas Paine to "Go on then in doing with your pen what in other times was done with the sword. ${ }^{[38]}$ Hence, if Nigerian writers cannot carry sword, can we carry pen to secure the nation?

\section{Conclusion}

Nigerian writers can build the bridge between the art and security by displaying their rare talents in proffering solutions to national issues of sociology, economy and politics. They can appropriate their writings for the process of mediation to capture the thoughts and full currents of the Nigerian contemporary security situations. This, in our opinion, will evolve and sustain a new era of literary rationalism with values placed on clarity, blunt social satire, moral didacticism, literary order, decorum and smoothness. By taking strong political stances and consequently exposing the conflicting facts about the security situation in the Nigerian Nation-State, writers can transform and redirect the nation's security system through literature. If they wade with dexterity into the security situation of the country with an awesome brand of transparent techniques and irony, targeted at proffering solutions to the deplorable security conditions in the country, perchance they can save and secure the nation. After all, "The ink of the scholar is more sacred than the blood of the martyr". ${ }^{[39]}$ It may be instructive to 
conclude our discussion with Adonis' statement on the occasion of Najib Mahfuz's Nobel Award that: "what secures today the Arabs' presence in the world is neither their oil nor their material richness; it is their intellectual creativity..." ${ }^{[40]}$

\section{References}

[1]. E.U. I., Alemika, and C. P. Nnorom, Criminal victimization, safety and policing in Nigeria: 2005. monograph series, No. 3 (Lagos: CLEEN Foundation, 2006)

[2]. A. Y. Al-Qurtubi, Jaamiu bayanil 'ilmi wa fadlihi (Egypt: Idarat Atiba'ah Al-Minbariyyah, n. d.), Vol. 1, 44

[3]. A. Saheed Adonis, Athabit wal-mutahawil, (Daar As-Saaqi, n.d.), Vol.4, 22

[4]. S. Wehmeier and M. Ashby, (eds.) Oxford advanced learner's dictionary (New Delhi: Oxford University Press, 2002)

[5]. G. Otto, and W.I. Ukpere, 'National security and development in Nigeria' in African Journal of Business Management Vol.6 (23), 2012, 6765-6770

[6]. O. Ibeanu, and A. Momoh, State responsiveness to public security needs: the politics of security decision-making (London: Russell Press Limited, 2008), p.13

[7]. Ibid.

[8]. Ibid.

[9]. . I. C. Achumba, et al, 'Security challenges in Nigeria and the implications for business activities and sustainable development' in Journal of Economics and Sustainable Development, Vol.4, No.2, 2013, 80 - 81.

[10]. D. Beland, The political construction of collective insecurity: from moral panic to blame avoidance and organized irresponsibility (Center for European Studies, 2005) Working Paper Series 126

[11]. C. Andrew, and M. Kennedy, Root causes of human insecurity in a new security paradigm The Cambridge Security Seminar, (University of Cambridge, 2003)

[12]. O. Igbuzor, Peace and Security Education: A Critical factor for sustainable peace and national development, International Journal of Peace and Development Studies Vol. 2 (1), 2011, 1-7

[13]. J. M. Hazen and J. Horner, Small arms, armed violence, and insecurity in Nigeria: the Niger Delta in perspective (Switzerland: Small Arms Survey, 2007)

[14]. B. Salawu, 'Ethno-religious conflicts in Nigeria: causal analysis and proposals for new management strategies' in European Journal of Social Sciences, Vol. 13, No. 3, 2010, 345-353

[15]. F. Fukuyama, State-building: governance and world order in the 21st century (Ithaca: Cornell University Press, 2004), in Achumba, I.C. et al, Op.cit. 81

[16]. C. Clifford, 'New beginnings' accessible on: www.cliffordchance.com

[17]. J. M. Hazen, and J. Horner, Op.cit.

[18]. .E. Edeko, 'The proliferation of small arms and light weapons in Africa: a case study of the Niger delta in Nigeria', in Sacha Journal of Environmental Studies, Vol. 1. No. 2, 2011, 55-80

[19]. G.L. Adeola and F. Oluyemi, 'The political and security implications of cross border migration between nigeria and her francophone neighbours', in International Journal of Social Science Tomorrow, Vol. 1, No. 3, 2012, 1-9

[20]. F.C. Onuoha, 'Nigeria's vulnerability to terrorism: the imperative of a counter religious extremism and terrorism' (CONREST) Strategy" Accesses on 9th April, 2014 at: http://www.monitor.upeace.org

[21]. D. Adedeji and O. I. Eziyi, 'Urban environmental problems in nigeria: implications for sustainable development', in Journal of Sustainable Development in Africa, Vol.12, No.1, 2010, 124-145

[22]. O. Adagba, et al., 'Activities of boko haram and insecurity question in Nigeria', in Arabian Journal of Business and Management Review,Vol. 1,No.9, 2012, 77- 99

[23]. http://www.azdema.gov/Terrorism. Retrieved: 10th April, 2014

[24]. G. Lamming, Social role of writers (Paris: United Nations Educational, Scientific and Cultural Organization, UNESCO, 1968), 2- 4

[25]. . M.A. Mahjub, Al-nahdah al-sudaaniyyah (Khartoum), no.255 in Oladosu, A.A, (2004), 'Authority versus Sexuality: Dialectics in Woman's Image in Modern Sudanese Narrative Discourse' in Hawwa Vol. 2, No.1,113 -139

[26]. E. Said, 'Representations of the Intellectual' The 1993 Reith Lectures, (New York: Pantheon Books, 1994), 11

[27]. Ibid. $11-12$

[28]. P. Stewart, (tr.) Children of gebelawi (London: Heineman, 1981), 3; the book was originally written in Arabic by Najib Mahfuz with the title, Awlad haratina, (Beirut: Darul Adab, 1967)

[29]. N. Mahfuz, As-sukkariyyah, (Cairo: Maktabat Misr, 1956), 91

[30]. H. Fallon et al, Silence Would Be Treason: Last Writings of Ken Saro-Wiwa, (eds.) (Dakar: Council for the Development of Social Science Research in Africa, 2013), 159

[31]. Check 'Nigeria authors and national security' in "Daily Independent" News Paper of Wednesday, March 27th, 2013

[32]. A. T. George, Ken Saro-Wiwa's art and the aesthetics of non-silence, doctoral diss. University of the Witwatersrand, Johannesburg, 2006.

[33]. P. Adesanmi, 'What does (Nigerian) literature secure?' Retrieved from: www.saharareporters.com on 17th April, 2014

[34]. [34] . 'Postcolonial African literature and the ideals of the open society/teaching and learning from Christopher Okigbo's poetry' in The International Journal of Poetry \& Graphics, No. 57, 2007, 2-3

[35]. C. Achebe, The Trouble with Nigeria quoted in A. T. George, Op.cit. 144

[36]. G. D. Killam and A. L. Kerfoot, Student encyclopedia of African literature (London: Greenwood Press, 2008), 305

[37]. C. Achebe, The role of the writer in a new nation, in G.D. Killam, (ed.) African Writers on African Writing (London: Heinemann, 1973), 7-13

[38]. C. P. Schneider and K. Nelson, Mightier than the sword: arts and culture in the U.S.- Muslim world relationship (Brookings: Saban Centre, 2008), 7

[39]. This is a saying of the Prophet Mohammed (P.B.U.H.). See J. L. Esposito, Islam: the Straight Path, (London: Oxford University Press, 1998), 81-82

[40]. M. T. Amyuni, 'The Arab artist's role in society: three case studies: Naguib Mahfouz, Tayeb Salih, and Elias Khoury' in Arabic and Middle Eastern Literatures, Vol. 2, No. 2, 1999, 221 - 222. 